\title{
Biogas utilization in an internal combustion engine working in a serial hybrid propulsion system
}

\begin{abstract}
Due to increase in demand for fossil fuels and aspects of natural environment protection, there is a major need to utilize alternative and renewable energy sources in order to promote sustainable development. The use of biogas as a source of renewable energy could provide effective and alternative way to satisfy a remarkable part of this demand for the transportation sector. As biogas has high inert content of carbon dioxide, its heating value is lower compared to CNG. Applying these low heating value renewable gaseous fuels for means of transport is not fully worked out yet because their combustion characteristics significantly differ from liquid fuels that are currently used or propane, or natural gas based systems that are becoming more and more popular in transportation. Biogas is not in common use, thus its utilization is recently limited for engines with conventional equipment burning other fuels. Thus, theoretical and experimental analysis was made to investigate the usability of biogas. On the basis of conducted investigation, it was found that effective biogas utilization as a fuel for means of transport can be achieved in a serial hybrid system consisted of internal combustion reciprocating engine.
\end{abstract}

Key words: fuels, internal combustion engines, power, natural gas, biogas, carbon dioxide

\section{Utylizacja biogazu w silniku spalinowym pracującym w napędzie hybrydowym szeregowym}

\begin{abstract}
Potrzeba zagospodarowywania alternatywnych źródet energii, w tym źródel odnawialnych, stymulowana jest koniecznościa zaspokojenia narastajacego zapotrzebowania na paliwa kopalne oraz ochrona środowiska naturalnego. Wykorzystanie biogazu jako źródła energii odnawialnej może być skutecznym a także alternatywnym środkiem do zaspokojenia znaczacej części tego zapotrzebowania na potrzeby sektora transportu. Biogaz, w porównaniu do CNG, charakteryzuje się mniejsza wartościa opałowa z powodu występowania w nim dużej ilości składnika niepalnego, jakim jest dwutlenek węla. Wykorzystanie tego niskokalorycznego paliwa gazowego na potrzeby środków transportu nie jest jeszcze w petni naukowo zbadane z powodu znaczacych różnic w zakresie przebiegu spalania w porównaniu do propanu, metanu lub paliw cieklych. Pomimo tego paliwa te staja się coraz bardziej popularne w sektorze transportu. Obecnie biogaz nie jest jeszcze powszechnie stosowany, dlatego jego wykorzystanie jako paliwa trakcyjnego jest ograniczane do klasycznych silników tlokowych standardowo spalajacych inne paliwa. Zatem w celu zbadania przydatności biogazu jako paliwa trakcyjnego przeprowadzono analize teoretyczna i badania eksperymentalne. Na podstawie przeprowadzonych badań uznano, że efektywne wykorzystanie biogazu jako paliwa do środków transportu można osiagnąć w wyniku jego spalania w szeregowym, hybrydowym zespole napędowym zawierajacym tłokowy silnik spalinowy.
\end{abstract}

Słowa kluczowe: paliwo, silnik spalinowy, moc, gaz ziemny, biogaz, dwutlenek węgla

\section{Introduction}

This paper is focusing on investigation into the combustion characteristics of biogas with respect to energetic utilization in a LPG or CNG fueled research engine working in a serial hybrid propulsion system. The utilization of the renewable alternative energy sources like liquid biofuels [13, $14,17]$ or biogas will have a major role in mitigating climate change while the increasing energy and mobility demand for mankind need to be satisfied and sustainable development should be maintained $[4,5,8,9,18]$. Renewable gaseous fuels like biogas utilized in gaseous engines can be managed as optional and effective way to meet a remarkable part of such demand [6, 14]. Firstly, authors have investigated construction of serial hybrid LPG vehicles, then, they have analyzed biogas utilization in such vehicles. The drivetrain of a vehicle is consisted of components that are responsible for transmitting power from the engine to the wheels of the

\section{Wstęp}

W artykule skoncentrowano się na badaniach nad charakterystyką spalania biogazu w silniku badawczym przystosowanym do paliw LPG lub CNG i wchodzącym w skład hybrydowego szeregowego zespołu napędowego. Energetyczna utylizacja paliw pochodzacych z odnawialnych źródeł energii - biopaliw ciekłych [13, 14, 17] lub biogazu może znacząco spowalniać zmiany klimatyczne związane z narastającym zapotrzebowaniem energii i transportu przez ludzkość $[4,5,8,9,18]$. Paliwa gazowe, takie jak biogaz, traktowane jako rezerwowe paliwa alternatywne stosowane do gazowego silnika spalinowego, mogą stanowić znaczący udział w tym ogólnym zapotrzebowaniu energetycznym $[6,14]$. Wstępnie przeanalizowano budowę pojazdów hybrydowych zasilanych LPG, a następnie możliwość wykorzystania biogazu do tych pojazdów. W zespole napędowym takiego hybrydowego pojazdu mogą występo- 
vehicle. With hybrids, there are three possible setups for the drivetrain as follows: the serial drivetrain, the parallel drivetrain, and the combined drivetrain. The serial drivetrain is the simplest hybrid configuration. In a serial hybrid, the electric motor is the only means of providing power to force vehicle's wheels turning. The wheel receives energy from either the battery pack or from a generator driven by an internal combustion engine. A computer determines how much of this energy comes from the battery or the engine/generator set. Both the engine/generator and regenerative braking recharge the battery pack. The internal combustion engine is typically smaller in a serial drivetrain because it only has to meet average driving power demands; the battery pack features generally with higher energy capacity than the one in parallel hybrids in order to provide remaining peak driving power needs. While the engine in a conventional vehicle is forced to operate inefficiently in order to satisfy varying power demands of stop-and-go driving, serial hybrids perform at their best in such conditions. This is because the internal combustion engine in a serial hybrid is not coupled to the wheels directly. This means the engine is no longer subject to the widely varying power demands experienced in stop-and-go driving and can instead operate in a narrow power range at near optimum efficiency. This also eliminates the need for a complicated multi-speed transmission system and a clutch. Because serial drivetrains perform best in stopand-go driving, they are primarily being considered for buses and urban vehicles.

\section{Theoretical investigation}

Within the transportation sector, the road transport market share is the largest in the EU and is still increasing due to

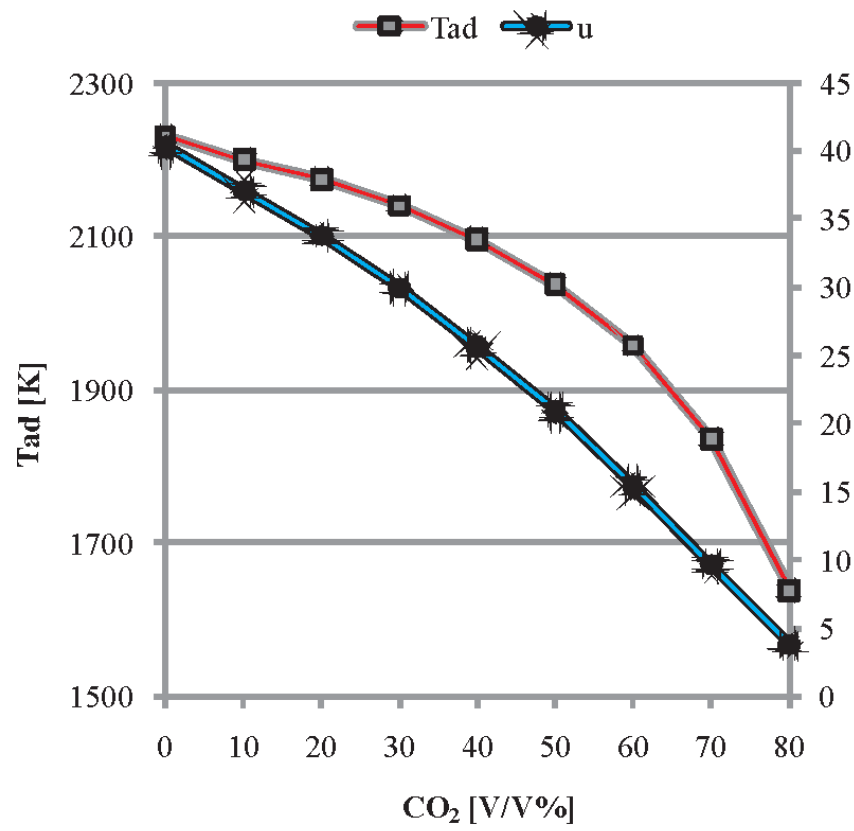

Fig. 1. Adiabatic flame temperature $\mathrm{T}_{\mathrm{ad}}$ and the laminar flame speed $\mathrm{u}$ of different biogas against $\mathrm{CO}_{2}$ content calculated at $\lambda=1 ; 273 \mathrm{~K} ; 101325 \mathrm{~Pa}$ [16] Rys. 1. Adiabatyczna temperatura płomienia $T_{\text {ad }}$ i prędkość spalania laminarnego $u$ dla biogazu o różnej zawartości $\mathrm{CO}_{2}$ obliczonych dla $\lambda=1,273 \mathrm{~K}, 101325 \mathrm{~Pa}[16]$ wać 3 warianty przeniesienia napędu na koła: szeregowo, równolegle lub w sposób mieszany. W szeregowym zespole napędowym, będącym jednocześnie najprostszym hybrydowym układem napędowym, silnik elektryczny służy wyłącznie do napędu kół i pobiera energię z akumulatorów lub z prądnicy, która jest napędzana silnikiem spalinowym. Komputer pokładowy pojazdu decyduje, jaka ilość energii ma być przekazywana z obydwu wymienionych źródeł. Bateria akumulatorów ładowana jest zarówno przez układ silnik spalinowy-prądnica, jak i w wyniku odzysku energii hamowania. W przypadku napędu hybrydowego szeregowego silnik spalinowy jest zazwyczaj mniejszy ze względu na pokrycie średniego zapotrzebowania mocy. Natomiast bateria akumulatorów charakteryzuje się większą moca w porównaniu do układu hybrydowego równoległego, ze względu na pokrycie szczytowego, chwilowego zapotrzebowania mocy. W tradycyjnym pojeździe silnik spalinowy pracuje w szerokim zakresie mocy i z tego powodu jego praca jest mało efektywna w porównaniu do napędu szeregowego hybrydowego, gdzie podczas pracy silnik ten cechuje się znacznie lepszymi osiągami, ponieważ jego obciążenie nie jest związane $\mathrm{z}$ chwilowym obciążeniem pojazdu, bo nie występuje sztywne przekazywanie mocy na koła. Zatem silnik ten nie jest już przedmiotem badań w zakresie cyklicznego obciążenia pojazdu postój-jazda, ale w znacznie węższym zakresie mocy zapewniającym osiągnięcie optymalnej sprawności. Ponadto zaletą takiego układu jest wyeliminowanie mechanicznych elementów przeniesienia napędu: skrzynia biegów, sprzęgło itp. Hybrydowe, szeregowe zespoły napędowe ze względu na swoje osiągi są rozważane jako potencjalne zespoły napędowe pojazdów komunikacji miejskiej.

\section{Analiza teoretyczna}

Udział transportu drogowego w skali całego transportu w Unii Europejskiej jest największy i $\mathrm{w}$ dalszym ciągu systematycznie się powiększa ze względu na wysoką jakość obsługi serwisowej (obsługa door-to-door), czasochłonność, żywotność i niezawodność [15]. Dlatego autorzy przeprowadzili badania wykorzystania biopaliwa gazowego w pojeździe hybrydowym z szeregowym zespołem napędowym przystosowanym do zasilania gazem CNG bez dokonywania modyfikacji silnika spalinowego tegoż zespołu. Biogaz jest głównie mieszaniną dwóch gazów: metanu i dwutlenku węgla. $\mathrm{CO}_{2} \mathrm{z}$ racji tego, że jest gazem niepalnym i jego ciepło właściwe jest względnie wysokie, negatywnie wpływa na osiagi silnika. Ponadto w wysokiej temperaturze spalania ulega dysocjacji na $\mathrm{CO}$ i $\mathrm{O}_{2}$ powodując spowolnienie przebiegu spalania. Wzrost udziału $\mathrm{CO}_{2}$ w biogazie wpływa także na zmniejszenie adiabatycznej temperatury płomienia $\mathrm{T}_{\mathrm{ad}}$ i jego prędkości u (rys. 1). Chociaż wyniki przedstawione na rysunkach $1-3$ dotyczą spalania w warunkach normalnego ciśnienia i temperatury, jednakże można wyciągnąć kilka wniosków w zakresie wpływu na parametry eksploatacyjne 
its superior service level (total flexibility in space door-todoor service) and time, reliability, speed and a lower probability of damage [15]. Authors have investigated the usage of gaseous biofuel in a serial CNG hybrid vehicle without any engine modification. Biogas has two major gaseous components: $\mathrm{CO}_{2}$ and methane. Methane is usually used in $\mathrm{CNG}$ engines. The $\mathrm{CO}_{2}$ content has a negative effect on the combustion properties of biogas because $\mathrm{CO}_{2}$ is a noncombustible component and its constant pressure specific heat is high, moreover it dissociates into $\mathrm{CO}$ and $\mathrm{O}_{2}$ at higher temperature, so it slows down the combustion process. By increasing the $\mathrm{CO}_{2}$ content, adiabatic flame temperature $\mathrm{T}_{\text {ad }}$ and flame speed u can be decreased (Fig. 1), which can cause burning instability and stretched combustion. Although, the Figures $1-3$ present results calculated at NTP conditions, but conclusions on engine performance can be drawn. Hence, decrease in flame temperature $T_{a d}$ and in the flame speed $u$ can lead to decrease in power and torque as concluded from the Fig. 1.

These two parameters (adiabatic flame temperature $\mathrm{T}_{\mathrm{ad}}$ $[\mathrm{K}]$, laminar flame velocity $\mathrm{u}[\mathrm{cm} / \mathrm{s}]$ ) are partly affected by the composition of the gaseous fuel. In case of $40 \%$ $\mathrm{CO}_{2}$ content, the lower heating value LHV of the gas is only around $20 \mathrm{MJ} / \mathrm{m}^{3}$ (Fig. 2). As far as the engine run is concerned, the Wobbe number of the gaseous fuel, apart from the LHV, is also a very important parameter. It corresponds to the heat load of the combustion device and can be calculated from:

$$
\text { Wo }=\frac{\text { HHV }}{\sqrt{\mathrm{n}}}
$$

where: HHV is the higher heating value $\left[\mathrm{MJ} / \mathrm{m}^{3}\right]$ and $n$ is relative density calculated from the densities of fuel $\left(\rho_{\text {fuel }}\right)$ and air $\left(\rho_{\text {air }}\right)$ :

$$
\mathrm{n}=\frac{\rho_{\text {fuel }}}{\rho_{\text {air }}}
$$

Even in case of gaseous fuels with the identical HVV, the Wobbe number can vary if composition of fuels is different due to their various relative densities. Concentrating on stable engine run, the variation of these two parameters should not vary more than $\pm 5 \%$. It is obvious that neither LHV nor the Wobbe number can be maintained in the required range in case of biogas operation, because typical biogas contains at least 30-40 V/V\% $\mathrm{CO}_{2}$ (Fig. 2) [13].

Another important parameter of combustion process is the $\mathrm{CO}_{2}$ emission. From the point of climate change, the $\mathrm{CO}_{2}$ is considered the main cause of global warming, thus, it is necessary to consider the fact that the $\mathrm{CO}_{2}$ content in biogas will remain in the atmosphere after combustion. Fig. 3 shows the maximum $\mathrm{CO}_{2}$ in the exhaust gas $\left(\mathrm{CO}_{2 \max }\right)$ and the exhaust gas volume $\left(\mathrm{V}_{\mathrm{o}}\right)$ of various biogases calculated under stoichiometric conditions. silnika. Zatem w wyniku obniżenia $\mathrm{T}_{\mathrm{ad}}$ i prędkości spalania laminarnego u można spodziewać się obniżenia osiągów silnika: jego mocy i momentu.

Wartości tych dwóch wielkości (adiabatyczna temperatura płomienia $\mathrm{T}_{\mathrm{ad}}[\mathrm{K}]$ i prędkość spalania laminarnego $\mathrm{u}[\mathrm{cm} / \mathrm{s}])$ częściowo zależą od składu chemicznego paliwa gazowego. Gdy zawartość $\mathrm{CO}_{2}$ wynosi $40 \%$, wówczas wartość opałowa LHV jest na poziomie około $20 \mathrm{MJ} / \mathrm{Nm}^{3}$ (rys. 2). W odniesieniu do paliw gazowych, poza wartością opałową LHV, istotny jest jeszcze jeden parametr - liczba Wobbe, która jest wskaźnikiem cieplnego obciążenia i jest zdefiniowana równaniem (1), gdzie: HHV - ciepło spalania $\left[\mathrm{MJ} / \mathrm{Nm}^{3}\right], \mathrm{n}$ - względna gęstość paliwa $\left(\rho_{\text {fuel }}\right)$ względem powietrza $\left(\rho_{\text {air }}\right)$ - wzór $(2)$.

Dla paliw gazowych o takich samych wartościach ciepła spalania HHV liczba Wobbe może być różna, gdy tylko różny jest skład chemiczny tych paliw gazowych, co wpływa na różną ich gęstość. Ze względu na stabilną pracę silnika spalinowego zmienność tych dwóch wielkości nie powinna przekraczać 5\%. Wydaje się oczywiste, że obydwie te wielkości dla biogazu nie mogą być utrzymywane w tak wąskim zakresie, ponieważ zazwyczaj produkowany biogaz charakteryzuje się zmiennością $\mathrm{CO}_{2} \mathrm{w}$ zakresie od 30 do 40\% (rys. 2) [13].

Jak się obecnie uważa, $\mathrm{CO}_{2}$ jest główną przyczyną globalnego ocieplenia, z tego względu emisja $\mathrm{CO}_{2}$ do atmosfery jest istotnym parametrem i dlatego też istotna jest zawartość $\mathrm{CO}_{2}$ w biogazie. Na rysunku 3 przedstawiono maksymalny udział $\mathrm{CO}_{2}$ w gazach spalinowych $\left(\mathrm{CO}_{2 \max }\right)$ i objętość tych gazów $\left(\mathrm{V}_{\mathrm{o}}\right)$ dla różnych biogazów przy stechiometrycznym warunku spalania.

Jak wynika $\mathrm{z}$ analizy rysunku 3 , wraz ze wzrostem zawartości $\mathrm{CO}_{2}$ w biogazie emisja $\mathrm{CO}_{2}\left(\mathrm{CO}_{2}\left[\mathrm{~m}^{3} / \mathrm{m}^{3}\right.\right.$ paliwa $\left.]\right)$ pozostaje na niezmienionym poziomie, aczkolwiek można zaobserwować wzrost $\mathrm{CO}_{2 \max }$ przy zmniejszaniu się ilości spalin $\left(\mathrm{V}_{\mathrm{o}}\right)$ przypadających na jednostkę objętości powie-

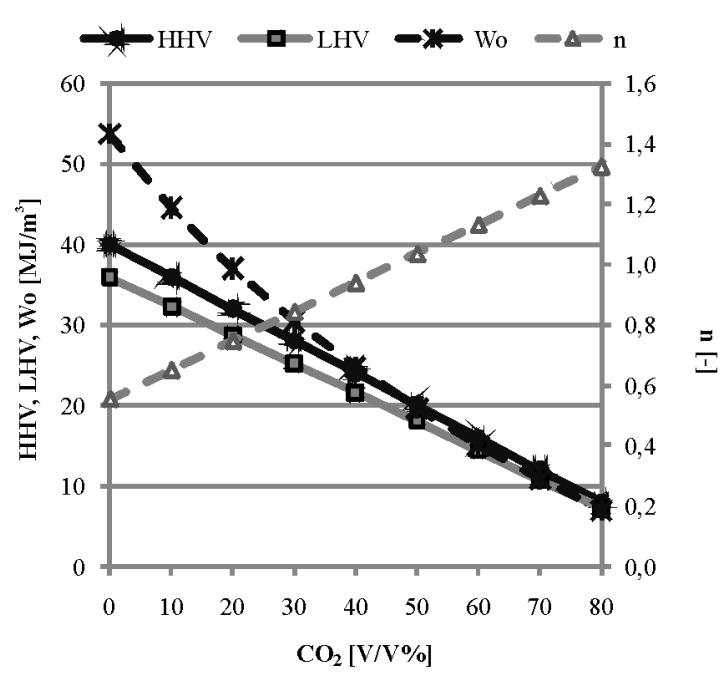

Fig. 2. LHV, the Wobbe number and the relative density values of different biogas against $\mathrm{CO}_{2}$ content, calculated at $273 \mathrm{~K}$ and $101325 \mathrm{~Pa}$ [16]

Rys. 2. LHV, liczba Wobbe $i$ względna gęstość dla biogazu o różnej zawartości $\mathrm{CO}_{2}$ obliczone dla $273 \mathrm{Ki} 101325 \mathrm{~Pa}$ [16] 


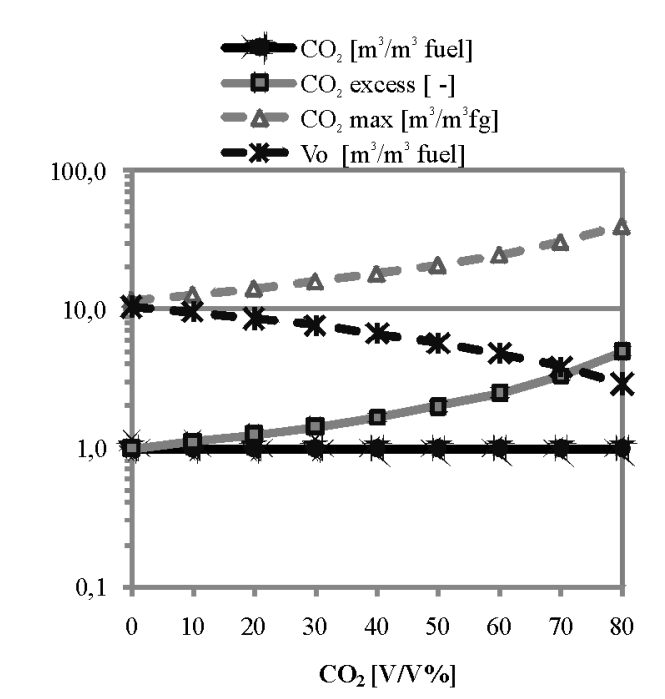

Fig. 3. The values of $\mathrm{CO}_{2 \max }, \mathrm{V}_{\mathrm{o}}$ and $\mathrm{CO}_{2}$ emission of different biogas against $\stackrel{\circ}{\mathrm{C}} \mathrm{O}_{2}$ content [16]

Rys. 3. Wartości $\mathrm{CO}_{2 \max }, V_{o}$ i emisji $\mathrm{CO}_{2}$ dla biogazów o różnej zawartości $\mathrm{CO}_{2}[16]$

As plotted in the Fig. 3, by increasing the $\mathrm{CO}_{2}$-content of biogas, the $\mathrm{CO}_{2}$ emission $\left(\mathrm{CO}_{2}\left[\mathrm{~m}^{3} / \mathrm{m}^{3}\right.\right.$ fuel] $)$ is constant, although $\mathrm{CO}_{2 \max } \%$ increases while the exhaust gas amount $\left(\mathrm{V}_{\mathrm{o}}\right)$ decreases. But if the decreased LHV of biogas is taken into account in the case of constant heat load, the $\mathrm{CO}_{2}$ emission of biogas is higher. But, presently, this $\mathrm{CO}_{2}$ excess does not have to be taken into account as far as global warming is concerned, because it was not produced from fossil fuel and the time scale of $\mathrm{CO}_{2}$ capture for biogas production and $\mathrm{CO}_{2}$ emission from biogas combustion is comparable which means that practically there is no excess $\mathrm{CO}_{2}$ emission in global scale.

\section{Experimental results}

The authors have analyzed biogas utilization in a serial hybrid CNG engine. The specification of both the engine and the power generator are as follows:

- gaseous Engine: 4 cylinders inline, brand: WISCON TOTAL TM27

- power: $24.6 \mathrm{~kW} / 1500 \mathrm{rpm}$

- bore x stroke: $91 \mathrm{~mm}$ x $103.2 \mathrm{~mm}$

- displacement: 2.681

- compression ratio: 11

- fixed spark timing: $30^{\circ} \mathrm{BTDC}$

- generator: MARELLI CX IM B3 180M, 26.4 kW/1500 rpm, 3 x $400 \mathrm{~V}, 50 \mathrm{~Hz}$

- gas mixture delivery: port fueled system consisted of a mixer.

Various compositions of biogas (mixture of $\mathrm{CO}_{2}$ and $\mathrm{CH}_{4}$ ) have been used to tests. The reference measurements were made with the $\mathrm{CH}_{4}$ fuel. Fig. 4 shows the change in specific fuel consumption of the engine fueled with various biogases. With increasing the $\mathrm{CO}_{2}$ content in biogas, to achieve the same power, the consumption needs to be increased due to decreasing the fuel heating value LHV. It is seen that this correlation is nonlinear. Moreover, the air to fuel ratio (AFR) trza. Wynika to z jednoczesnego zmniejszania się LHV przy niezmiennym obciążeniu cieplnym silnika. Ponadto ta nadwyżka $\mathrm{CO}_{2}$ nie powinna być uwzględniana w limitach emisji związanych z globalnym ociepleniem, ponieważ nie pochodzi ze spalania paliw kopalnych oraz należy uwzględnić fakt, że emisja $\mathrm{CO}_{2}$ jest zbilansowana jeśli chodzi o produkcję i następnie spalanie biogazu. Zatem, praktycznie ujmując, spalanie biogazu nie przyczynia się do wzrostu poziomu $\mathrm{CO}_{2}$ w skali globalnej.

\section{Badania eksperymentalne}

Autorzy przeprowadzili analizę utylizacji biogazu w laboratoryjnym silniku badawczym na paliwo CNG zamontowanym w układzie hybrydy szeregowej. Dane silnika i prądnicy są następujące:

- silnik: 4-cylindrowy, rzędowy, typ: WISCON TOTAL TM27

- moc 24,6 kW/1500 obr/min

- średnica x skok: $91 \mathrm{~mm}$ x 103,2 mm

- pojemność skokowa: 2,68 $\mathrm{dm}^{3}$

- stopień sprężania: 11

- stały kąt zapłonu: $30^{\circ}$ przed ZZP

- prądnica: MARELLI CX IM B3 180M, 26,4 kW/1500 obr/min, 3 x 400V, $50 \mathrm{~Hz}$.

- dostarczanie mieszaniny gazów: mieszalnik zainstalowany na kanale dolotowym silnika.

Użyty do badań biogaz o różnej zawartości $\mathrm{CO}_{2}$ był tworzony jako mieszanina gazów $\mathrm{CO}_{2} \mathrm{i} \mathrm{CH}_{4}$. Ponadto dokonano pomiarów, spalając $\mathrm{CH}_{4}$ jako paliwo odniesienia. Na rysunku 4 przedstawiono jednostkowe zużycie biogazu przez silnik. Ze wzrostem zawartości $\mathrm{CO}_{2}$ i tym samym zmniejszaniem się jego wartości opałowej, aby utrzymywać taką samą moc wyjściową, należało zwiększać ilość paliwa dostarczanego do silnika. Można zauważyć, że zależność ta nie jest liniowa. Ponadto można zaobserwować, że wpływ współczynnika stechiometrii powietrza do paliwa (AFR) na zmianę zawartości $\mathrm{CO}_{2}$ wzrasta ze wzrostem zawartości $\mathrm{CO}_{2}$ w biogazie, co widać na rysunku w postaci powiększającego się gradientu odpowiednich krzywych.

Pomimo że ilość ciepła wydzielona jest niezmienna, występuje spadek mocy silnika ze wzrostem zawartości $\mathrm{CO}_{2}$ w biogazie, ponieważ duży udział składnika niepalnego wpływa na niezupełny przebieg spalania [7]. Zjawisko to zaobserwowano również podczas spalania przy podwyższonym współczynniku AFR (rys. 5). Dla wartości $\mathrm{CO}_{2}$ powyżej $30 \%$ i dla AFR > 1,3 moc silnika znacząco się zmniejszała, pomimo że zwiększano odpowiednio dawkę biogazu zużywanego przez silnik.

Podobny przebieg jak dla mocy zaobserwowano dla sprawności ogólnej silnika (BTE) - rys. 6. Znaczący spadek sprawności obserwuje się dla $\mathrm{CO}_{2}$ powyżej $30 \%$ i dla AFR $>1,3$. Gdy zawartość $\mathrm{CO}_{2}$ w biogazie wynosi powyżej $45 \%$, sprawność ogólna (BTE) spada do połowy wartości maksymalnej będącej wartością odniesienia. Ponadto zmiana współczynnika AFR bardziej oddziaływuje na zmianę sprawności aniżeli zmiana stężenia $\mathrm{CO}_{2} \mathrm{w}$ biogazie, jak to pokazano na rysunku 6 za pomocą gradientu odpowiednich krzywych. 


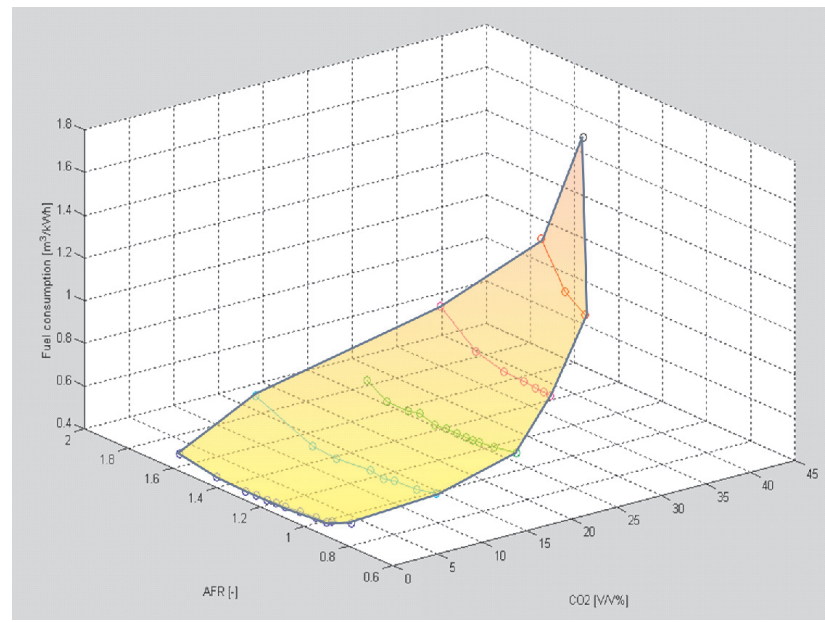

Fig. 4. Experimental result of change in specific fuel consumption $\left[\mathrm{m}^{3} / \mathrm{kWh}\right]$ (source: own measurement)

Rys. 4. Zmiana jednostkowego zużycia paliwa $\left[\mathrm{m}^{3} / \mathrm{kWh}\right]$

sensitivity of specific consumption increases with increasing the biogas $\mathrm{CO}_{2}$ content, that is shown by the higher gradient of the curves in the Figure 4.

However, the heat load is constant due to increase in the specific consumption, the increase of $\mathrm{CO}_{2}$ content in biogas reduces the power due to both high non-combustible content in biogas and its incomplete combustion [7]. Furthermore, the same phenomena can be observed with increase in the air to fuel ratio AFR (Fig. 5). Above $30 \mathrm{~V} / \mathrm{V} \% \mathrm{CO}_{2}$ and AFR $>1.3$ the power decreases, so in case of such combustion circumstances even with increased biogas consumption, less power can be achieved.

The brake thermal efficiency (BTE) features with the same trend as was observed for power with increase in the $\mathrm{CO}_{2}$ content of biogas (Fig. 6). As remarkable power change can only be detected above $30 \mathrm{~V} / \mathrm{V} \% \mathrm{CO}_{2}$ and AFR $>1.3$ and the heat load is constant, the decrement in BTE is caused by the power drop. Therefore, in case of $45 \mathrm{~V} / \mathrm{V} \% \mathrm{CO}_{2}$ content of biogas, the BTE is less than half of the reference. Moreover, the AFR impact on the BTE is stronger than impact of

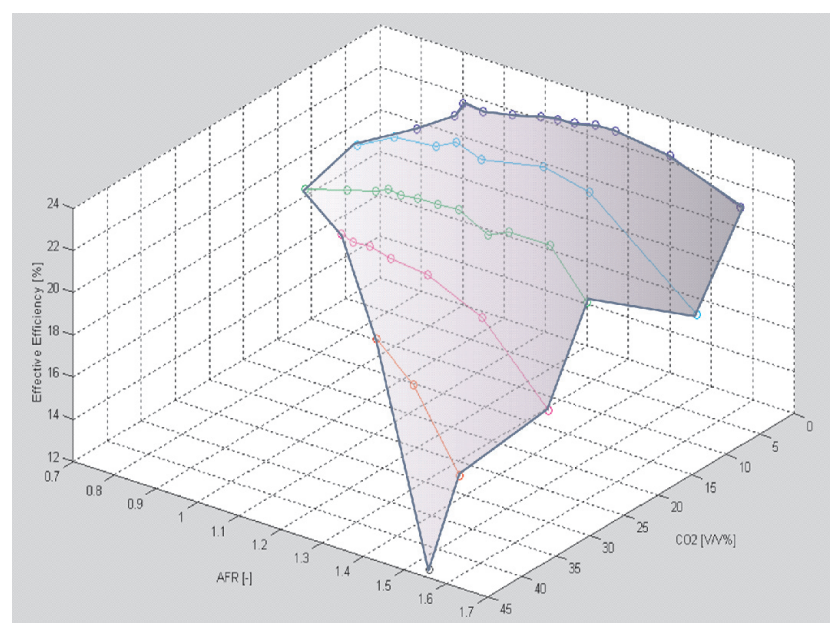

Fig. 6. Experimental result of change in effective efficiency BTE [\%] (source: own measurement)

Rys. 6. Zmiana sprawności efektywnej [\%]

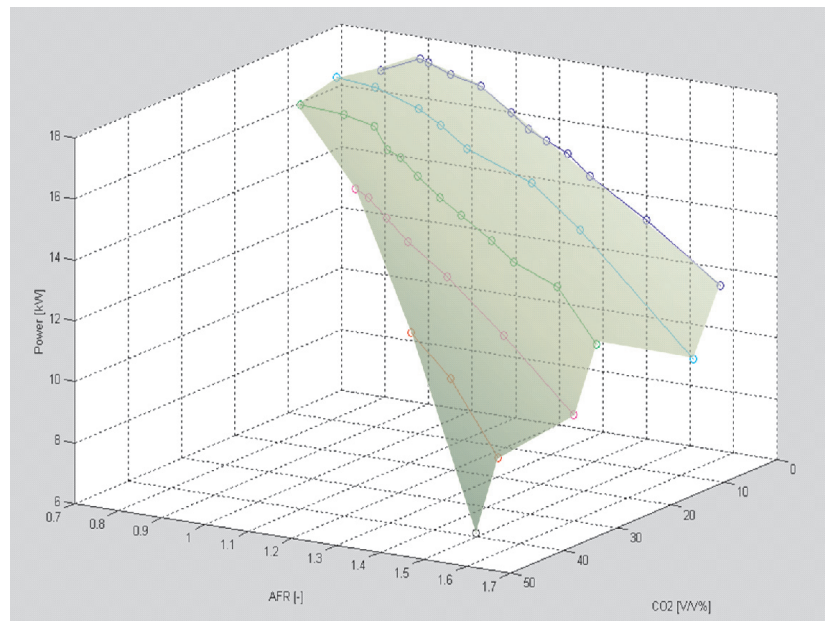

Fig. 5. Experimental result of change in break power $[\mathrm{kW}]$ (source: own measurement)

Rys. 5. Zmiana mocy efektywnej silnika [kW]

Jak przedstawiono na rysunku 7, w zadowalającej korelacji z mocą efektywną silnika jest stężenie $\mathrm{CO}_{2}$ w gazach spalinowych. Zgodnie z oczekiwaniami na podstawie badań teoretycznych, emisja $\mathrm{CO}_{2}$ rośnie ze wzrostem zawartości $\mathrm{CO}_{2}$ w biogazie.

Gdy $\mathrm{CO}_{2}$ w biogazie przekroczy $30 \%$, przy której to wartości obserwuje się znaczący spadek mocy silnika, następuje znaczny przyrost emisji $\mathrm{CO}_{2}$ w spalinach (rys. 8). Podobnie jak poprzednio, przyrost ten jest nieliniowy, ale jednocześnie jest on zgodny z oczekiwaniami wynikającymi z rozważań teoretycznych $[2,3,10]$. Dlatego spadek mocy silnika wynikający ze zmiennej zawartości $\mathrm{CO}_{2} \mathrm{w}$ biogazie powinien być uwzględniany przy analizie osiągów tego silnika.

Nie tylko emisja $\mathrm{CO}_{2}$, ale także emisja $\mathrm{NO}, \mathrm{CO}$ i THC są istotnymi parametrami analizy silnika zasilanego biogazem. Do tworzenia NO głównie przyczynia się temperatura spalania. Zatem wraz ze wzrostem zawartości $\mathrm{CO}_{2} \mathrm{w}$ biogazie emisja NO ulega zmniejszaniu m.in. z powodu obniżenia temperatury spalania w wyniku akumulowania większej

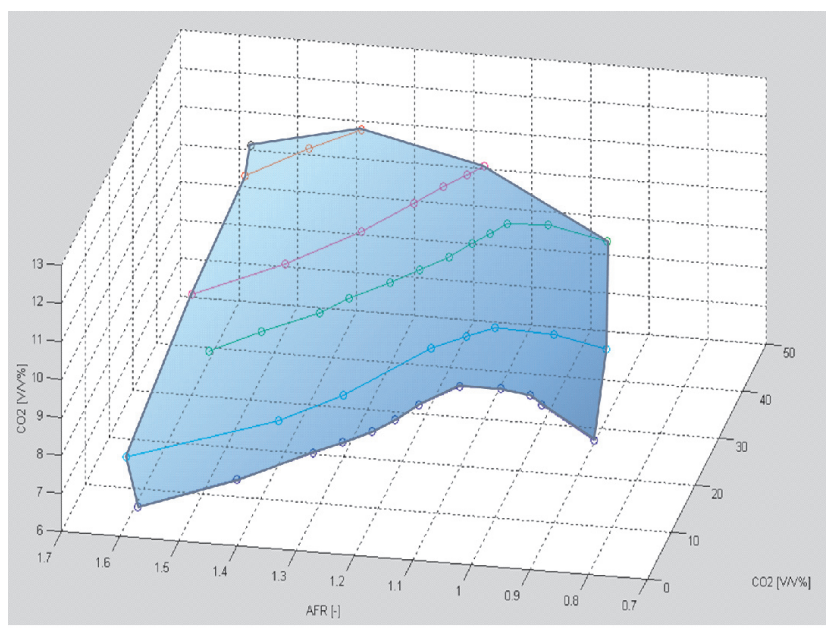

Fig. 7. Experimental result of change in carbon dioxide emissions [V/V\%] (source: own measurement) Rys. 7. Zmiana emisji dwutlenku węgla [V/V\%] 
the $\mathrm{CO}_{2}$ content in biogas, as it is shown by the higher gradient of the curves in the Figure 6.

As observed in the Fig. 7 the $\mathrm{CO}_{2}$ emission of the exhaust gas is in satisfactory correlation with the break power. As it was expected from the theoretical calculations, the $\mathrm{CO}_{2}$ emission from the engine increases with increasing the $\mathrm{CO}_{2}$ content in biogas.

Above $30 \mathrm{~V} / \mathrm{V} \%$ $\mathrm{CO}_{2}$ further increase in the $\mathrm{CO}_{2}$ content in biogas contributes to significant power drop, even if fuel consumption was increased to maintain

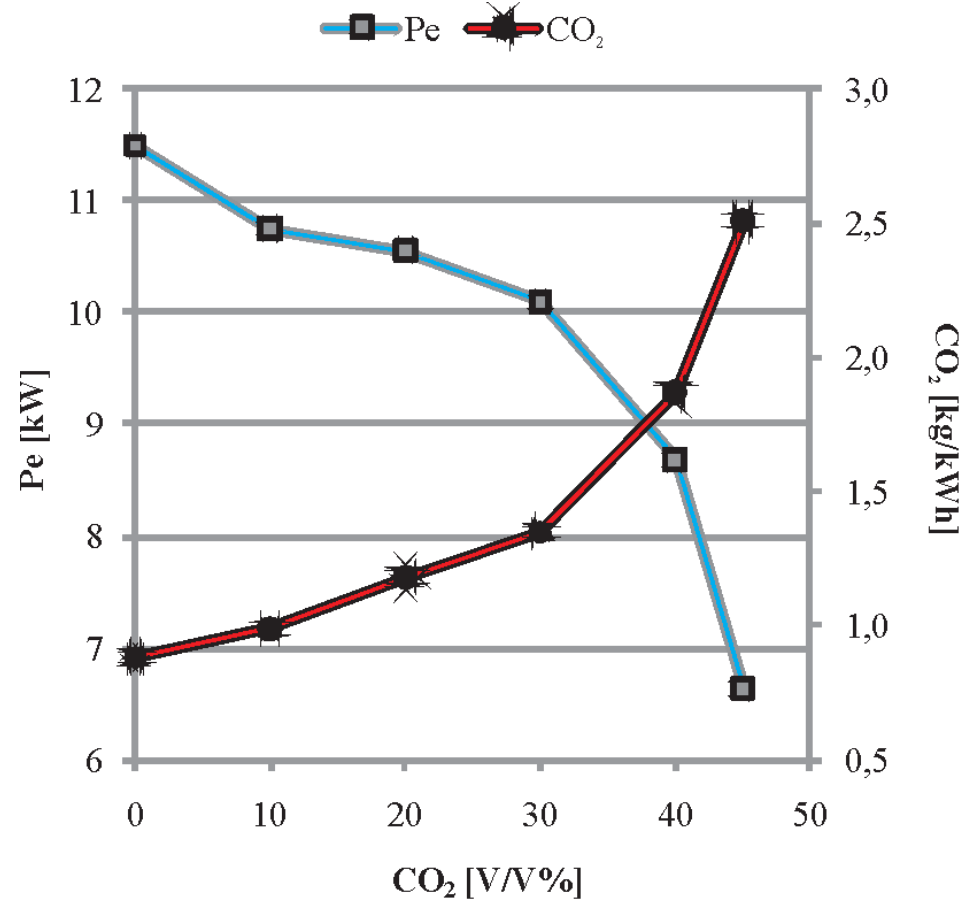

Fig. 8. $\mathrm{CO}_{2}$ content in the exhaust gases and break power $\mathrm{P}_{\mathrm{e}}$ against the $\mathrm{CO}_{2}$ emission of biogas (source: drawn by own measurement)

Rys. 8. Emisja $\mathrm{CO}_{2}$ i moc efektywna w zależności od zawartości $\mathrm{CO}_{2}$ w biogazie ilości ciepła przez wzrastającą zawartość $\mathrm{CO}_{2}$ i jego dysocjację. Gdy zawartość $\mathrm{CO}_{2}$ w biogazie jest na poziomie $30 \%$, emisja NO zmniejsza się o połowę względem wartości referencyjnej dla czystego metanu. Występuje tutaj także zadowalająca korelacja pomiędzy NO i sprawnością efektywną BTE oraz występowaniem największej emisji NO przy AFR $=1,1$. Emisje pozostałych istotnych produktów niezupełnego spalania $(\mathrm{CO}, \mathrm{THC})$ przedstawiono na rysunku 9b i 9c. Pomimo że zawartość $\mathrm{CO}_{2}$ w biogazie wpływa na spowolnienie przebiegu spalania, to nie stwierdzono znaczącego wzrostu CO i THC w spalinach, nawet gdy $\mathrm{AFR}=1,4$, chociaż można przypusz- the heat load constant. This increased consumption causes excess $\mathrm{CO}_{2}$ emission. The increment of $\mathrm{CO}_{2}$ emission is also nonlinear, however, it is in good correlation with the results from theoretical calculations $[2,3,10]$.

Hence, remarkable power drop, noticed in the case of $\mathrm{CO}_{2}$ fluctuation in biogas with constant average $\mathrm{CO}_{2}$ content, should be considered during engine performance analysis.

Not only the $\mathrm{CO}_{2}$ emission, but $\mathrm{NO}, \mathrm{CO}$ and THC emissions of the biogas fueled engine are important parameters as well (Fig. 9a-c). NO formation is mainly affected by combustion temperature, therefore with increase in the $\mathrm{CO}_{2}$ content in biogas the NO emission is reduced due the temperature drop caused by the heat accumulation and dissociation of higher amounts of the $\mathrm{CO}_{2}$. In case of $30 \mathrm{~V} / \mathrm{V} \% \mathrm{CO}_{2}$ the highest $\mathrm{NO}$ emission is nearly half of the reference number for metane combustion. The NO emission shows good correlation with BTE as the highest NO emissions are also around AFR $=1.1$.

The other significant products of incomplete combustion $(\mathrm{CO}, \mathrm{THC})$ are shown in Figures $9 \mathrm{~b}$ and 9c. However, the $\mathrm{CO}_{2}$ content of biogas lengthens combustion, no remarkable increase in the $\mathrm{CO}$ and THC exhaust emission is observed at the $\mathrm{AFR}=1.4$, however, the combustion might be completed in the exhaust pipe before taking a sample of the exhaust gases for their analysis. Further leaning the combustible mixture to $\mathrm{AFR}=1.55$ and $45 \mathrm{~V} / \mathrm{V} \% \mathrm{CO}_{2}$ leads to increase in the THC emission by nearly one and a half times more and the $\mathrm{CO}$ emission by three times more than the reference number for pure metane combustion. czać, że mogły one ulec dopalaniu w kanale wydechowym spalin, tuż przed punktem poboru próbki gazów spalinowych do analizy. Dalsze zubożanie mieszanki do wartości AFR $=1,55$ przy zawartości $\mathrm{CO}_{2} \mathrm{w}$ biogazie na poziomie $45 \%$ prowadziło do półtorakrotnego zwiększenia emisji THC i trzykrotnego zwiększenia emisji CO w odniesieniu do wartości referencyjnej dla spalania czystego metanu.

\section{Wnioski}

Na podstawie przeprowadzonych badań teoretycznych i eksperymentalnych w zakresie spalania biogazu w trakcyjnym silniku spalinowym można wywnioskować, że wykorzystanie biogazu jako paliwa w środkach transportu jest ograniczone głównie z powodu przewlekłego przebiegu spalania tego gazu ze względu na występowanie w nim dwutlenku węgla w relatywnie dużej ilości. Ponadto zakres efektywnej pracy silnika ulega zawężeniu wraz ze wzrostem zawartości $\mathrm{CO}_{2} \mathrm{w}$ biogazie, a w skrajnym warunku eksploatacji dla ilości $\mathrm{CO}_{2}$ w biogazie powyżej 45\% silnik przestaje pracować. Ze wzrostem zawartości $\mathrm{CO}_{2} \mathrm{w}$ biogazie rośnie również jednostkowe zużycie biogazu przez silnik i rośnie emisja $\mathrm{CO}_{2}$ do atmosfery. Zaobserwowano również zmniejszanie mocy silnika pomimo utrzymywania stałej wartości energii dostarczanej w paliwie.

Zatem zasilany biogazem silnik spalinowy przeznaczony do napędu środków transportu powinien pracować przy ściśle stałym obciążeniu ze względu na uzyskanie względnie dużej mocy wyjściowej i równego biegu przy swojej najwyższej sprawności efektywnej. Na tej podstawie można stwierdzić, że silnik taki powinien pracować w układzie hybrydowym szeregowym. Jednym z punktów zwrotnych w kierunku 


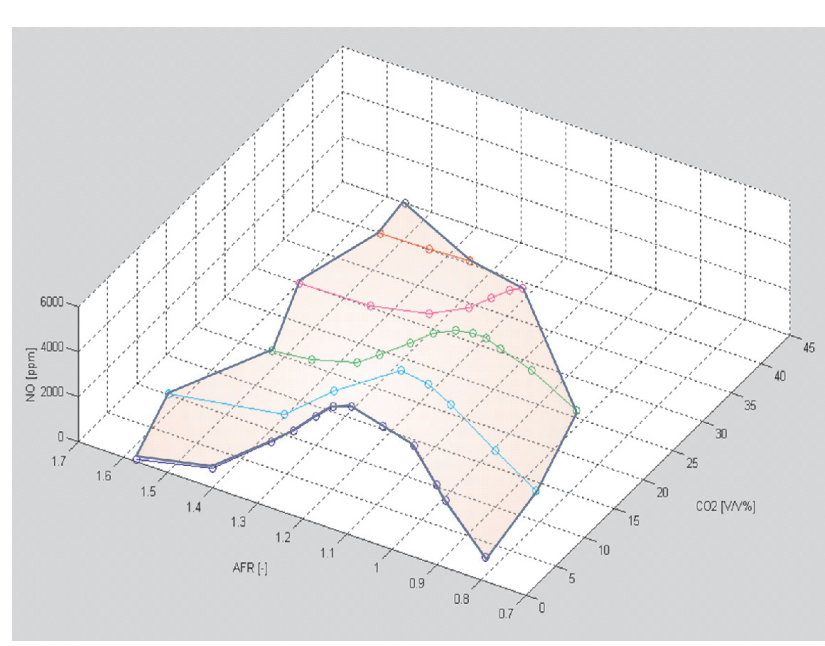

Fig. 9a. Experimental result of change in nitrogen oxide emission [ppm] (source: drawn by own measurement)

Rys. 9a. Zmiana stężenia NO [ppm]

\section{Conclusion}

Considering both the theoretical investigations and the tests of biogas combustion in the traction internal combustion engine, one can conclude that the transport-related utilization of biogas in gaseous engines is limited mainly due to lengthening combustion process by relatively high carbon dioxide content in the biogas. Additionally, the effective operation range of the engine is getting narrow with increasing the $\mathrm{CO}_{2}$ content in biogas and, at the given operation circumstances above $45 \mathrm{~V} / \mathrm{V} \% \mathrm{CO}_{2}$, the engine cannot run. As biogas consumption in the IC engine increases with increase in $\mathrm{CO}_{2}$ in biogas, so does the $\mathrm{CO}_{2}$ emission. $\mathrm{A}$ negative correlation between $\mathrm{CO}_{2}$ and engine break power is also observed, even though, the energy in fuel delivered to the engine was maintained constant.

Thus, the internal combustion engine working on biogas and applied as a propulsion system for means of transport should work at strictly constant load with respect to obtain satisfactory power output and smooth run at its maximal break effective efficiency. That resulted to apply the engine combined in a serial hybrid system for this purpose. One of the cornerstones in transition towards more climate-friendly on-road mobility schemes is stimulation for technological innovations in engine exhaust gases emission reduction, particularly through improving fuel economy and moving transportation away from its dependence on crude oil to a more sustainable track.

\section{Acknowledgements}

This work was realized under frames of bilateral HungarianPolish collaboration and the scientific program of the "Development of quality-oriented and harmonized $\mathrm{R}+\mathrm{D}+\mathrm{I}$ strategy and functional model at BME" project. These projects are supported by the New Széchenyi Plan (Project ID: TÁMOP-4.2.1/B-09/1/KMR-20100002 and "Modelling and multi-objective optimization based control of road traffic flow considering social and economical aspects" program CNK 78168 of OTKA. This paper is supported of Bólyai János Research fellowship of HAS (Hungarian Academy of Science).

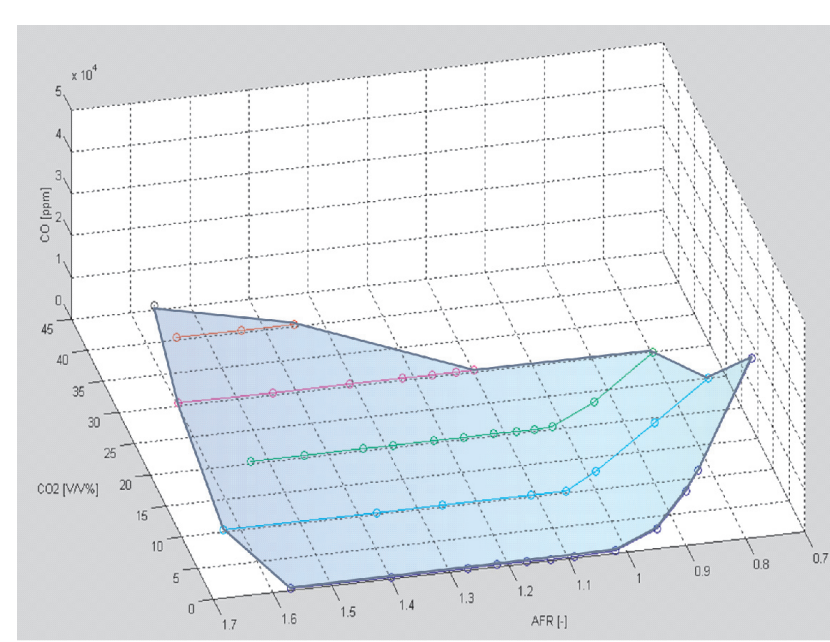

Fig. 9b. Experimental result of change in carbon monoxide emission [ppm] (source: drawn by own measurement)

Rys. 9b. Zmiana stężenia CO [ppm]

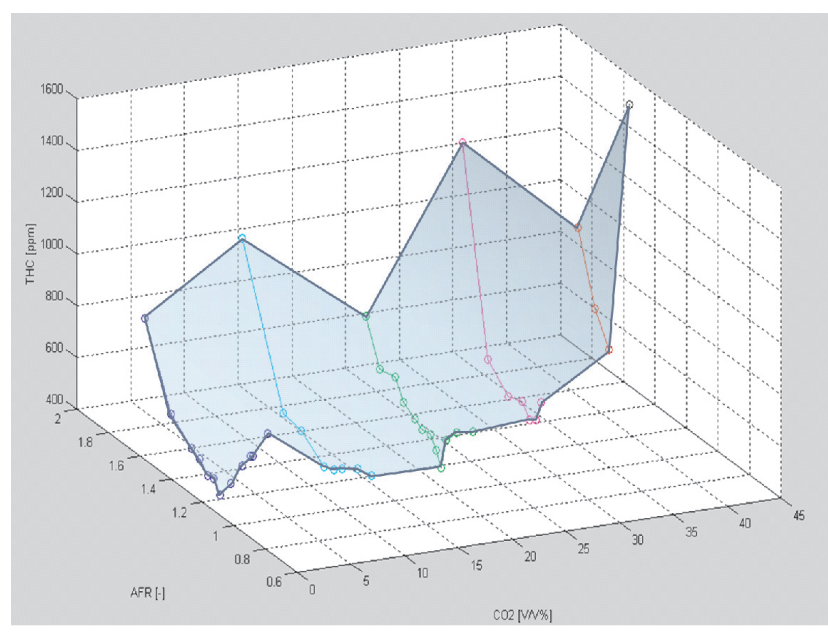

Fig. 9c. Experimental result of change in total hydrocarbon emission [ppm] (source: drawn by own measurement)

Rys. 9c. Zmiana stężenia THC [ppm]

doskonalenia ruchu drogowego na bardziej przyjazny środowisku jest stymulowanie badań innowacyjnych w zakresie redukcji gazów spalinowych, szczególnie przez poprawianie ekonomiki spalania i uniezależnianie się od ropy naftowej.

\section{Podziękowanie}

Badania były realizowane w ramach dwustronnej współpracy polsko-węgierskiej i w ramach projektu naukowego zatytułowanego „Development of quality-oriented and harmonized $\mathrm{R}+\mathrm{D}+\mathrm{I}$ strategy and functional model at BME". Badania w tym projekcie były finansowane przez New Széchenyi Plan (Project ID: TÁMOP4.2.1/B-09/1/KMR-2010-0002 oraz "Modelling and multi-objective optimization based control of road traffic flow considering social and economical aspects" - program nr CNK 78168 OTKA). Ten artykuł uzyskał wsparcie stypendialne OD Bólyai János Research Węgierskiej Akademii Nauk

Paper reviewed/Artykut recenzowany 


\section{Bibliography/Literatura}

[1] Bokor Z.: Hungary: role of the state in intermodal transport logistics services, Logistics and Transport Focus 9(8): 37-41, 2007.

[2] Henham A., Makkar M.K.: Combustion of simulated biogas in a dual-fuel diesel engine, Energy Conversion and Management 39(16-18): 2001-2009. doi:10.1016/S0196-8904(98)00071-5, 1998.

[3] Huang J.D., Crookes R.J.: Assessment of simulated biogas as a fuel for the spark ignition engine, Fuel 77(15): 1793-1801. doi:10.1016/S0016-2361(98)00114-8, 1998.

[4] Kugelevičius J.A., Kuprys A., Kugelevičius J.: Forecasts of petroleum demand, Transport 22(1): 9-13, 2007.

[5] Kuprys A., Kugelevičius J.: Possibilities of using liquefied oil gas in transport, Transport 24(1): 48-53. doi:10.3846/16484142.2009.24.48-53, 2009.

[6] Meggyes A., Bereczky Á.: Kapcsolt gázmotorok energetikai vizsgálata [Energetic analysis of combined gas engine systems], Energetics [Energetika], 15(3):18-22 (in Hungarian), 2007.

[7] Porpatham E., Ramesh A., Nagalingam B.: Investigation on the effect of concentration of methane in biogas when used as a fuel for a spark ignition engine, Fuel 87(8-9): 1651-1659. doi:10.1016/j.fuel.2007.08.014, 2008.

[8] Tánczos K., Török A.: The linkage between climate change and energy consumption of Hungary in the road transportation sector, Transport 22(2): 134-138, 2007.

[9] Török Á.: Theoretical estimation of the environmental impact of biofuel mixtures, Transport 24(1): 26-29. doi:10.3846/16484142.2009.24.26-29, 2009.

[10] Uma R., Kandpal T.C., Kishore V.V.N.: Emission characteristics of an electricity generation system in diesel alone and dual fuel modes, Biomass \& Bioenergy 27(2): 195-203. doi:10.1016/j.biombioe.2004.01.003, 2004.

[11] Bereczky Á.: Utilisation of biofuels in internal combustion engines, in Proceedings of 8th Conference on Heat Engines and Environmental Protection, 28-30 May, 2007, Balatonfüred, 43-47, 2007.
[12] Penninger A., Meggyes A., Bereczky A., Grof G., Konczol S., Lezsovits F., Sztanko K., Kovacs V. B.: Utilization of gas mixtures having high inert content generated from biomass in gas-engine and in gasturbine, 22th German Flame Day, VDI-Berichte 1888 (ISSN: 0083-5560), 267-272. Paper II-21, 2005.

[13] Kovács V.B., Meggyes A., Bereczky Á.: Investigation of utilization of pirolysis gases in IC engine, in Proceeding of Sixth Conference on Mechanical Engineering, Budapest, Hungary, May 30-31 2008, 153-157.

[14] Laza T., Bereczky Á.: Repceolaj és magasabb rendü alkoholok párolgási konstansának meghatározása, [Determination of the evaporation constant in case of pure and with alcohol mixed rape seed oil], in 16th International Conference in Mechanical Engineering, Brasso, Romania, May 1-4, 2008, 232237. (in Hungarian).

[15] Török Á.: Climate change and road transportation sector, in Proceedings of the International Conference on Environmental Management, Engineering, Planning and Economics(CEMEPE), Skiathos, June 24-28, 2007, 2569-2574.

[16] Török Á., Kovács V.B.: Investigation on transport related biogas utilization. Transport Journal Of Vilnius Gediminas Technical University And Lithuanian Academy Of Sciences 25:(1), pp. 77-80, (2010).

[17] Szendrő G.: Sustainable biofuels in Hungary and Europe self-defeating incentives? Gazdálkodás Scientific Journal on Agricultural Economics, Vol.54. Special Edition No.24, pp.71-78, 2010.

[18] Für A. Csete M.: Modeling methodologies of synergic effects related to climate change and sustainable energy management. Periodica Polytechnica Social and Management Sciences, 18/1, 2010, pp.11-19.
Viktoria Barbara Kovacs, DEng. - Budapest University of Technology and Economics, Dept. of Energy Engineering, Budapest, Hungary.

Dr inż. Viktoria Barbara Kovacs - Budapeszteński Uniwersytet Techniczno-Ekonomiczny, Wydziat Inżynierii Energii, Budapeszt, Węgry.

e-mail:kovacsv@energia.bme.hu

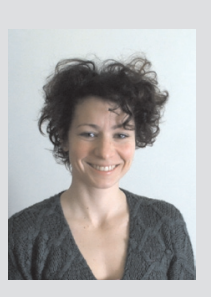

Akos Bereczky, DSc., DEng. - Budapest University of Technology and Economics, Dept. of Energy Engineering, Budapest, Hungary.

Dr inż., Akos Bereczky, prof. BUTE, Budapeszteński Uniwersytet Techniczno-Ekonomiczny, Wydziat Inżynierii Energii, Budapeszt, Węgry.

e-mail:bereczky@energia.bme.hu

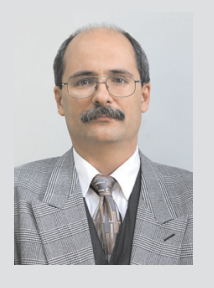

Adam Torok, DEng. - Budapest University of Technology and Economics, Dept. of Transport Economics, Budapest, Hungary

Dr inż. Adam Torok-Budapeszteński Uniwersytet Techniczno-Ekonomiczny, Wydzial Ekonomii Transportu, Budapeszt, Wegry.

e-mail:torok@kgazd.bme.hu

Stanisław Szwaja, DEng. - doctor in the Faculty of Mechanical Engineering and Computer Science at Częstochowa University of Technology.

Dr inż. Stanisław Szwaja - adiunkt na Wydziale Inżynierii Mechanicznej i Informatyki Politechniki Częstochowskiej.

e-mail:szwaja@imc.pcz.czest.pl 